\title{
Marketing performance as implication of brand image mediated by trust
}

\author{
Arfendo Propheto ${ }^{a^{*}}$, Dwi Kartini ${ }^{b}$, Sucherly $^{b}$ and Yevis Marty Oesman ${ }^{b}$
}

${ }^{a}$ Student at Padjadjaran University, Bandung and Lecturer of Kusuma Negara Business Scholl, Indonesia ${ }^{b}$ Padjadjaran University, Bandung, Indonesia

\section{H R O N I C L E}

\begin{tabular}{l}
\hline Article history: \\
Received: September 52019 \\
Received in revised format: Sep- \\
tember 8 2019 \\
Accepted: October 23, 2019 \\
Available online: \\
October 23, 2019 \\
\hline Keywords: \\
Brand Image \\
Trust \\
Marketing Performance
\end{tabular}

\section{A B S T R A C T}

Research on marketing performance has been discussed by several previous researchers on institutions and industries. One of them is in the field of education. The purpose of this study is to analyze the effect of brand image toward marketing performance, brand image on trust and brand image toward marketing performance mediated by trust. In previous studies there have been many studies that measure marketing performance from internal or management perspective. On the other hand, this research discusses marketing performance that can be measured through the perspective of the student as consumer. This research studies the marketing performance of private higher education in the perspective of students in the Indonesian context. This research was conducted in DKI Jakarta. In this study it was found that there was not a significant influence on brand image toward marketing performance; brand image has a significant influence on trust and also trust towards marketing performance; but brand image has a significant influence toward marketing performance mediated by trust.

\section{Introduction}

Higher education plays an important role in competitiveness in the global economy. The Word Economy Forum since 2004 has published a Global Competitiveness Index (GCI), which is a parameter or standard measure that can indicate the level of excellence of a country compared with other countries throughout the world. Competitiveness is seen as the ability of a country to develop institutions, formulate policies, and grow the factors that trigger economic productivities. These three aspects will ultimately determine the level of prosperity that can be achieved by the state. Based on GCI for 2016-2017, according to Schwab and Sala-i-Martin (2016) Indonesia is in 41st position out of 138 countries, down from the previous year where Indonesia was in 37th position. In the Asia Pacific region, Indonesia's position is still behind Singapore, Japan, Hong Kong, New Zealand, Taiwan, Malaysia, South Korea, China, and Thailand. Based on these data it is indicated that the level of competitiveness of Indonesia is still categorized low and based on notes from Schwab and Sala-i-Martin (2016) Indonesia is even categorized as only superior in terms of market size alone. It is hoped that Indonesia's competitiveness position can be increased through the role of private higher education. The development of private higher education will contribute in improving Indonesia's competitive position in the fifth pillar of the 12 pillars that support a country's GCI, namely higher education and training. DKI Jakarta has the second highest Private higher education after West Java Province. DKI Jakarta has 96 Academies, 10 Polytechnics, 177 Colleges, 22 Institutes, 29 Universities and 1 Community Academy. With the total area of DKI Jakarta, which is $661.5 \mathrm{~km}^{2}$, the density of Private higher education in DKI Jakarta Province is the highest in other provinces in Java, as well as in Indonesia. Furthermore, the 2015 Annual Report of the Ministry of Research, Technology and Higher Education records that of the top six ranking higher education with international accreditation, only 1 private higher education has received international accreditation. The number of private higher education in DKI Jakarta, in 2013 was 336 decreased to 335 and 331 in 2014 and 2015 and experienced an increase in 2016 and 2017 to 333 and 334, or in other words fluctuating compared with population growth which continues to increase every year. This indicates the marketing performance in private higher education is still unsteady, especially in DKI Jakarta. according. Wardoyo (2014) in his research stated that the marketing * Corresponding author.

E-mail address: arfendo89@gmail.com (A. Propheto) 
performance of the most supportive tertiary institutions was related to information to students about accreditation as a promotional medium used.

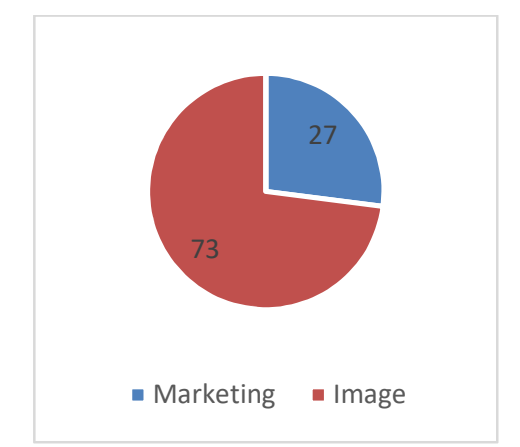

Fig. 1. Selection of private higher education based on the image

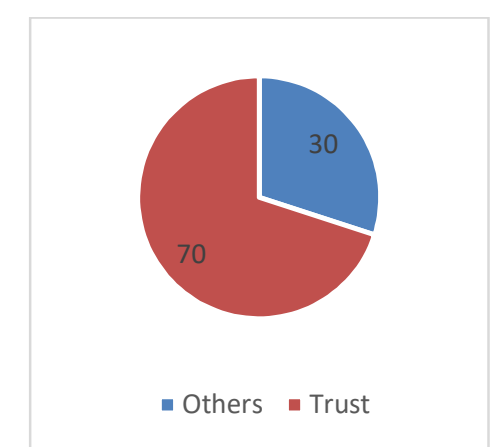

Fig. 2. Selection of private higher education based on the trust

Source: Preliminary Survey 2017 (data processed)

Based on Fig. 1, it appears that $73 \%$ of the students choose private higher education based on imagery compared with the latest information. The high selection of private higher education by students based on that image was not followed by an improved private higher education performance. This can be seen from the number of private higher education that is still volatile every year. Data from the research results of the university consultants stated that the selection of private higher education by students was based on a good private higher education image. The percentage of the image of a private higher education is one indication that is very supportive in its marketing performance. Based on Fig. 2 , it can be seen that $70.01 \%$ of the private higher education selection is based on trust and $29.99 \%$ of the selection of private higher education is based on other factors. This shows that the influence of trust towards prospective students is quite high, but this is inversely proportional with the marketing performance of private higher education which is still volatile. Based on empirical and theoretical phenomena that have been described, the purpose of this study is to determine the marketing performance of private higher education which is influenced by brand image and trust directly and brand image toward marketing performance mediated by trust (mediating effect).

\section{Literature review}

\subsection{Brand Image}

The image for the company is useful for instilling what the company has and offers in the mind of the seller (Muniz \& O'Guinn, 2001). Brand image can also be useful to place a company in a certain position in the market. A brand can have multiple images. The brand can reflect the consumer's view of the product as well as the company of the product., Davidson et al. (2007) argue that "a strong brand image, a rich and long history, the ability for the product to be publicly consumed and the threat of competition, all make a brand more predisposed to community formation". In other words, a strong image is the result of the company's long history and the ability of the products produced by the company to be widely consumed and pose a threat to competition. This opinion was further explained by Hawkins et al. (2005) who stated that brand image "refers to the memory of a brand scheme, which contains consumer interpretation of the attributes, advantages, use, situations, users, and characteristics of marketers and / or characteristics of the manufacturer of the products / brands". It was explained that users of certain products will be affected by their views of the brand after using or buying the goods or services offered, whether positive or negative. If an image has been attached to consumers as a brand that has a good product or service, the brand image owned by the company will be known as a good image. This explanation is in line with Hubanic and Hubanic (2009) which states that brand image reflects consumer perceptions of brand characteristics and can be determined based on the association. The image itself refers to the way consumers interpret the signs that come from the product, including service and communication by the brand. According to Keller (1993) there are three types of brand associations, namely (1) attributes: descriptive features that can characterize a product or service; (2) benefit: personal assessment of consumers attached to a product or service, namely the consumers' mind about what a product or service can do for them; and (3) attitudes: the average evaluation of a brand. Brand attitudes are considered important because they often form the basis of consumer behavior such as brand choices.

\subsection{Trust}

Trust in marketing industry is conceptualized in (Ulaga \& Eggert, 2005) as a feature of relationship quality (Dwyer et al.,1987), and as a determinant of relationship quality (Anderson \& Weitz, 1992). Trust is quite important in relational exchange. According to Morgan and Hunt (1994), trust is a cornerstone of the strategic partnership since the characteristics of relationships through trust are so valuable that a group wishes to carry out a commitment to itself over the relationship. Similar conditions also occur in the consumer market where the level of competition between companies is very high. Following the strategy carried out by industrial companies, consumer goods companies try to build relationships with consumers (Ishak \& 
Lutfi, 2011: 59). This is done by building consumer confidence in the company's product brands. Lau and Lee (1999) show that when consumers believe that certain brands are able to give what they expect will bring about brand loyalty. According to Tsai et al. (2010: 276-277) the party given the trust should realize the expectations of the trustee without reaching consumer vulnerability into profit. Trust is considered as a tool to believe that certain parties can be trusted (reliable)

\subsection{Marketing Performance}

According to Clark (1999), the dimensions of non-financial marketing performance are market share, quality of service adaptability, customer satisfaction and customer loyalty. Marketing performance offered by Clark is used in this study because it can evaluate marketing performance from the student perspective.

\section{Hypotheses}

\subsection{Brand image and customer trust}

Hypothesis 1: Brand Image has positively and significantly effect on trust.

\subsection{Brand image and marketing performance}

Hypothesis 2. Brand Image has positively and significantly effect on marketing performance.

\subsection{Customer trust and marketing performance}

Hypothesis 3:. Customer trust has positively and significantly effect on marketing performance

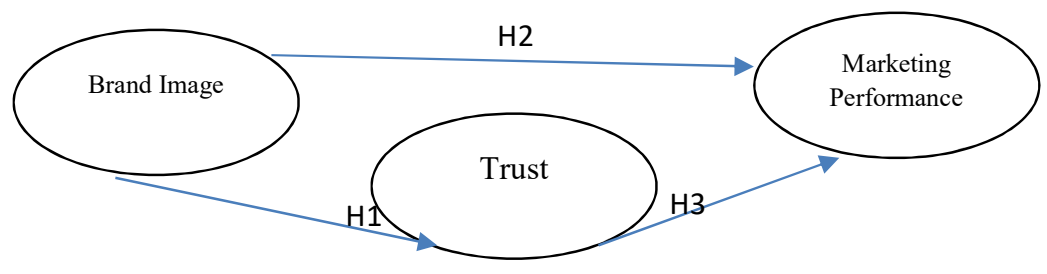

\section{Methodology, results and discussion}

Fig. 3. Research Model

The data used in this study are obtained by distributing questionnaires directly, and the unit of analysis in this study is students at Private higher education in DKI Jakarta. The sampling technique uses probability sampling with proportionate stratified random sampling method, and the samples obtained are 334 respondents. Data are analyzed using the Structural Equation Modeling (SEM) method using the Lisrel V.8.8 software.

\subsection{Descriptive Analysis}

Respondents' responses related to brand images, trust, and marketing performance are strongly agreed. This is indicated by the average value of each variable which is $4.26 ; 4.25$; and 4.3 . So it can be said that the assessment of students from each private higher education at DKI Jakarta Chapter on the brand image, trust and marketing performance has met the needs of students.

Table 1

Descriptive Variable Image, Integrated Marketing Communication, Trust, and Marketing Performance

\begin{tabular}{|c|c|c|c|}
\hline No. & Variable & average & description \\
\hline 1 & Brand image & 4,26 & Strongly agree \\
\hline 2 & Trust & 4,25 & Strongly agree \\
\hline 3 & Marketing Performance & 4,3 & Strongly agree \\
\hline
\end{tabular}

Source: Data processing (2019)

\subsection{Validity and Reliability Test}

Before testing the hypotheses, a validity and reliability test for each research variable is carried out (Table 2 and Table 3 ). Standardized Factor Loading of Observed Variable on Latent Variable (loading factors) $>0.50$ and the cut-off level to be able to say that the composite reliability $(\mathrm{CR})>0.6$ and Average Variance Extracted (AVE) $>0.5)$. From Table 2 it is found that all indicators are valid (loading factors $>0.5$ ) and based on the Table 3 all the dimensions formed by the indicators are reliable $(\mathrm{CR}>0.6$ and $\mathrm{AVE}>0.5)$. 
Table 2

Validity Test Result

\begin{tabular}{|c|c|c|c|c|}
\hline Variables & Dimension & Item & Loading Factors & Conclusion \\
\hline \multirow[t]{8}{*}{ Brand } & \multirow[t]{3}{*}{ Attributes } & $\mathrm{x} 11$ & 0.92 & Good validity \\
\hline & & $\mathrm{x} 12$ & 0.97 & Good validity \\
\hline & & $\mathrm{x} 13$ & 0.90 & Good validity \\
\hline & \multirow[t]{3}{*}{ Benefits } & $\mathrm{x} 14$ & 0.93 & Good validity \\
\hline & & $\mathrm{x} 15$ & 0.81 & Good validity \\
\hline & & $\mathrm{x} 16$ & 0.51 & Good validity \\
\hline & \multirow[t]{2}{*}{ Reputation } & $\mathrm{x} 17$ & 0.96 & Good validity \\
\hline & & $\mathrm{x} 18$ & 0.96 & Good validity \\
\hline \multirow[t]{8}{*}{ Trust } & \multirow[t]{3}{*}{ Reliable } & $\mathrm{y} 11$ & 0.96 & Good validity \\
\hline & & y12 & 0.88 & Good validity \\
\hline & & y13 & 0.97 & Good validity \\
\hline & \multirow[t]{2}{*}{ Honest } & y14 & 0.98 & Good validity \\
\hline & & $\mathrm{y} 15$ & 0.93 & Good validity \\
\hline & \multirow[t]{3}{*}{ Benevolent } & y16 & 0.96 & Good validity \\
\hline & & y17 & 0.87 & Good validity \\
\hline & & y18 & 0.94 & Good validity \\
\hline Marketing & \multirow[t]{3}{*}{ Satisfaction } & $\mathrm{y} 21$ & 0.71 & Good validity \\
\hline \multirow[t]{8}{*}{ Performance } & & $\mathrm{y} 22$ & 0.81 & Good validity \\
\hline & & $\mathrm{y} 23$ & 0.72 & Good validity \\
\hline & \multirow[t]{3}{*}{ Loyalty } & $\mathrm{y} 24$ & 0.72 & Good validity \\
\hline & & $\mathrm{y} 25$ & 0.80 & Good validity \\
\hline & & y26 & 0.73 & Good validity \\
\hline & \multirow[t]{3}{*}{ Product Excellence } & $\mathrm{y} 27$ & 0.72 & Good validity \\
\hline & & $\mathrm{y} 28$ & 0.75 & Good validity \\
\hline & & $\mathrm{y} 29$ & 0.71 & Good validity \\
\hline
\end{tabular}

Source: Data processing (2019)

Table 3

Reliability Test Result

\begin{tabular}{|c|c|c|c|c|}
\hline Variable & Dimension & Composite Reliability & Average Variance Extracted & Conclusion \\
\hline \multirow[t]{3}{*}{ Brand } & Attributes & 0.96 & 0.88 & Reliable \\
\hline & Benefits & 0.90 & 0.72 & Reliable \\
\hline & Reputation & 0.98 & 0.93 & Reliable \\
\hline \multirow[t]{3}{*}{ Trust } & Reliable & 0.97 & 0.91 & Reliable \\
\hline & Honest & 0.96 & 0.92 & Reliable \\
\hline & Benevolent & 0.96 & 0.88 & Reliable \\
\hline Marketing & Satisfaction & 0.86 & 0.67 & Reliable \\
\hline \multirow[t]{2}{*}{ Performance } & Loyalty & 0.87 & 0.69 & Reliable \\
\hline & Product Excellence & 0.86 & 0.68 & Reliable \\
\hline
\end{tabular}

Source: Data processing (2019)

\subsection{Model Structure Analysis}

The accuracy of the SEM model (Overall Model Fit) is then performed to evaluate in general the degree of compatibility or goodness of fit (GOT) between the data and the model. The estimation model results can be said to be good if they meet the model fit requirements (Table 4). From Table 4 it can be seen that all the results of the analysis of the suitability of the whole model, GOF which shows Good Fit, so that the overall fit of the model can Fit.

Table 4

Goodness of Fit Result

\begin{tabular}{|c|c|c|c|c|c|}
\hline Indicators and Value & Standard Value & Remarks & Indicators and Value & Standard Value & Remarks \\
\hline $\mathrm{NFI}=0.98$ & $\geq 0.90$ & Good Fit & $\mathrm{RFI}=0.97$ & $\geq 0.90$ & Good Fit \\
\hline $\mathrm{NNFI}=0.98$ & $\geq 0.90$ & Good Fit & $\mathrm{RMR}=0.0078$ & $\leq 0.10$ & Good Fit \\
\hline $\mathrm{CFI}=0.99$ & $\geq 0.90$ & Good Fit & $\mathrm{GFI}=0.94$ & $\geq 0.90$ & Good Fit \\
\hline $\mathrm{IFI}=0.99$ & $\geq 0.90$ & Good Fit & $\mathrm{AGFI}=0.91$ & $\geq 0.90$ & Good Fit \\
\hline
\end{tabular}

Source: Data processing (2019)
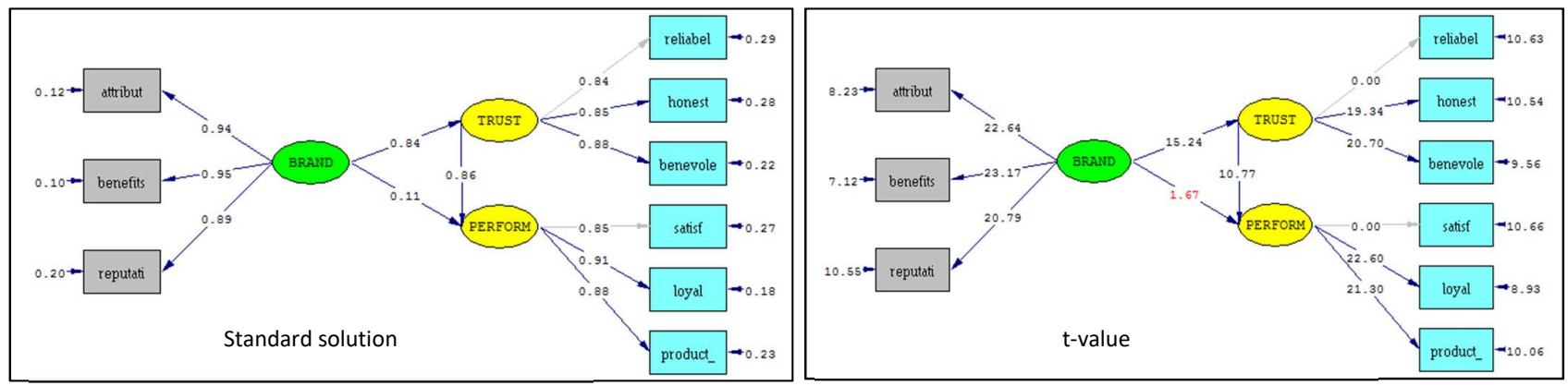

Fig. 4. Path Diagram Structural Model Source: Data processing (2019) 
From Table 5 it is found that all the t-values of each manifest forming latent variables are greater than 1.96, thus it can be stated that the validity of all manifest variables forming latent variables (brand, trust and marketing performance) is good. CR value $>0.6$ and AVE value $>0.5$, then the manifestation of forming latent variables (brand, trust and marketing performance) is good. Manifest variables that provide the strongest contribution in shaping latent brand variables are benefits (0.95), subsequently attributes $(0.94)$ and finally reputation (0.89). Next the trust variable, the manifest variable that contributes most strongly is benevolent $(0.88)$, then honest $(0.85)$ and finally reliable $(0.84)$. Finally, marketing performance variables, manifest variables that contribute most strongly are loyalty $(0.91)$, then product excellence $(0.88)$ and finally satisfaction $(0.85)$.

Table 5

Manifest Variables forming Latent Variables

\begin{tabular}{|c|c|c|c|c|c|}
\hline Variables & Dimension & t-value & Loading Factors & Composite reliability (CR) & Average Variance Extracted (AVE) \\
\hline \multirow[t]{3}{*}{ Brand } & Attributes & 22.64 & 0.94 & \multirow{3}{*}{0.95} & \multirow{3}{*}{0.86} \\
\hline & Benefits & 23.17 & 0.95 & & \\
\hline & Reputation & 20.79 & 0.89 & & \\
\hline \multirow[t]{3}{*}{ Trust } & Reliable & $* * *$ & 0.84 & \multirow{3}{*}{0.89} & \multirow{3}{*}{0.74} \\
\hline & Honest & 19.34 & 0.85 & & \\
\hline & Benevolent & 20.7 & 0.88 & & \\
\hline \multirow{3}{*}{$\begin{array}{c}\text { Marketing } \\
\text { Performance }\end{array}$} & Satisfaction & $* * *$ & 0.85 & \multirow{3}{*}{0.91} & \multirow{3}{*}{0.77} \\
\hline & Loyalty & 22.6 & 0.91 & & \\
\hline & Product Excellence & 21.3 & 0.88 & & \\
\hline
\end{tabular}

Source: Data processing (2019)

Table 6

Result of Hypotheses Test

\begin{tabular}{|c|c|c|c|c|c|}
\hline Hypotheses pathway & $\begin{array}{l}\text { Hypotheses rela- } \\
\text { tionship }\end{array}$ & $\begin{array}{l}\text { Standardize Co- } \\
\text { efficient }\end{array}$ & t-statistics & $\begin{array}{l}\text { Tested hypoth- } \\
\text { eses }\end{array}$ & Result \\
\hline Brand $\rightarrow$ trust & Positive & 0.84 & 15.24 & H1 & Supported \\
\hline Brand $\rightarrow$ marketing performance & Positive & 0.11 & 1.67 & $\mathrm{H} 2$ & Not Supported \\
\hline Trust $\rightarrow$ marketing performance & Positive & 0.86 & 10.77 & H3 & Supported \\
\hline
\end{tabular}

Table 7

Effect among latent variable on the overall sample

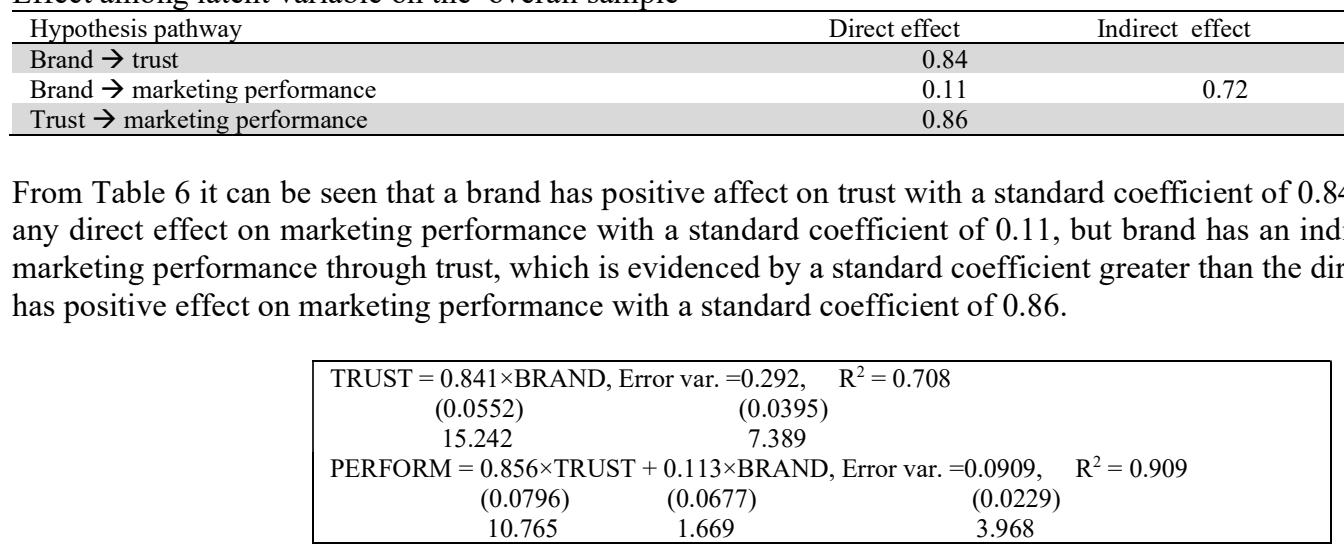

Fig. 5. Structural Equation Model

From Fig. 5 it is found that the brand has an influence of $70.8 \%\left(\mathrm{R}^{2}=0.708\right)$ on trust, while trust and brand have influences on marketing performance of $90.9 \%\left(\mathrm{R}^{2}=0.909\right)$.

\subsection{Discussion}

Customer trust is certainly very important in various fields. No exception in the field of education, namely students as customers. Therefore an important role for a good marketing image is needed to attract and retain students. Trust is crucial in choosing private higher education when consumers do not really evaluate what attributes are needed or what attributes offered by private higher education according to their needs according to Cuffaro and Di Giancinto (2015). The results of this study are in line with several previous studies conducted by Fianto et al. (2014), Rivai and Wahyudi (2017) and Flavián et al. (2005) who state that there is a significant influence between image and trust. According to Sutarso (2017), where trust is used as one of the research variables on marketing performance with significant results. The theory was advanced by Moorman et al. in Ishak and Luthfi (2011) which defines trust as a willingness to depend on other parties who have been trusted. Trust contains two different aspects, namely credibility which refers to the belief that the other party has expertise in carrying out their duties and benevolence which refers to the sincerity of the other party that he has the sincerity to carry out as agreed. This explains the importance of consumer confidence for the company. With a long-term cooperative relationship, companies can work 
more effectively by saving transaction costs to improve performance. The success of an educational institution in this case Higher Education will ultimately determine its sustainability in operating for the long term. One of the things that needs to be done is how to know the College Marketing Performance. To be able to achieve university marketing performance one way is to increase student confidence. To be able to achieve their trust, efforts can be made by maintaining the image of the institution well, so that they will trust the institution in which they are studying.

\section{Conclusion}

From the analysis of data and the results of hypothesis testing, it is found that brand image has a positive and significant influence on trust, this shows that a good image of a private university will be able to increase student trust. Likewise trust has a positive and significant effect on marketing performance, which shows that the more trust students have in a private university can actually improve marketing performance. However, brand image does not have any effect on marketing performance directly but has an indirect effect on marketing performance through trust. This means that to improve marketing performance, private universities must increase the trust of their students.

\section{Acknowledgement}

The author would like to thank the Ministry of Research, Technology and Higher Education and Kopertis III Region of DKI Jakarta for supporting this research.

\section{References}

Anderson, E., \& Weitz, B. (1992). The use of pledges to build and sustain commitment in distribution channels. Journal of marketing research, 29(1), 18-34.

Clark, B. H. (1999). Marketing performance measures: History and interrelationships. Journal of Marketing Management, 15(8), 711-732.

Cuffaro, N., \& Di Giacinto, M. (2015). Credence goods, consumers' trust in regulation and high quality exports. Bio-based and Applied Economics Journal, 4(1050-2016-85715), 179-197.

Davidson, L., McNeill, L., \& Ferguson, S. (2007). Magazine communities: brand community formation in magazine consumption. International Journal of Sociology and Social Policy, 27(5/6), 208-220.

Dwyer, F. R., Schurr, P. H., \& Oh, S. (1987). Developing buyer-seller relationships. Journal of marketing, 51(2), 11-27.

Fianto, A. Y. A., Hadiwidjojo, D., \& Aisjah, S. (2014). The influence of brand image on purchase behaviour through brand trust. Business Management and Strategy, 5(2), 58.

Flavián, C., Guinaliu, M., \& Torres, E. (2005). The influence of corporate image on consumer trust: A comparative analysis in traditional versus internet banking. Internet Research, 15(4), 447-470.

Hawkins, I. D., Best, J. R., \& Coney, A. K. (2003). Consumer Behaviour Building Marketing Stratergy.

Hubanic, A., \& Hubanic, V. (2009). Brand identity and brand image a case study of Nordstan brand. University Of Gothenburg School Of Business, Economics And Law.

Ishak, A., \& Luthfi, Z. (2011). Pengaruh kepuasan dan kepercayaan konsumen terhadap loyalitas: Studi tentang peran mediasi switching costs. Jurnal Fakultas Hukum UII, 15(1).

Keller, K. L. (1993). Conceptualizing, measuring, and managing customer-based brand equity. Journal of marketing, 57(1), $1-22$.

Lau, G. T., \& Lee, S. H. (1999). Consumers' trust in a brand and the link to brand loyalty. Journal of Market-Focused Management, 4(4), 341-370.

Wardoyo, M. (2014), pengaruh kinerja promosi dan kerelasian mahasiswa terhadap citra. Sosiohumaniora, 16(1), 64-69.

Muniz, A. M., \& O'guinn, T. C. (2001). Brand community. Journal of Consumer Research, 27(4), 412-432.

Morgan, R. M., \& Hunt, S. D. (1994). The commitment-trust theory of relationship marketing. Journal of marketing, 58(3), 20-38.

Schwab, K., \& Sala-i-Martin, X. (2016). The Global Competitiveness Report 2016-2017. World Economic Forum Reports 2016. http://doi.org/92-95044-35-5

Sutarso, Y., Halim , R. E., Balqiah, T. E., \& Tjiptoherijanto, P. ( 2017). The Role of Co-creation Activities, Trust and Gender on Higher Education Marketing Performance. European Research Studies Journal Volume XX, Issue 3A, , 825-845.

Tsai, M. T., Chin, C. W., \& Chen, C. C. (2010). The effect of trust belief and salesperson's expertise on consumer's intention to purchase nutraceuticals: Applying the theory of reasoned action. Social Behavior and Personality: an international journal, 38(2), 273-287.

Ulaga, W., \& Eggert, A. (2005). Relationship value in business markets: the construct and its dimensions. Journal of Businessto-business Marketing, 12(1), 73-99.

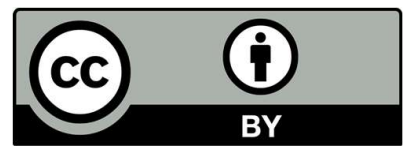

(C) 2020 by the authors; licensee Growing Science, Canada. This is an open access article distributed under the terms and conditions of the Creative Commons Attribution (CC-BY) license (http://creativecommons.org/licenses/by/4.0/). 